\title{
Effect of Fermentation Process on Nutritional Composition and Aflatoxins Concentration of Doklu, a Fermented Maize Based Food
}

\author{
Marina C. N. Assohoun ${ }^{1,2}$, Théodore N. Djeni ${ }^{1 *}$, Marina Koussémon-Camara ${ }^{1}$, Kouakou Brou $^{2}$ \\ ${ }^{1}$ Department of Biotechnology and Food Microbiology, University Nangui Abrogoua, Abidjan, Côte d'Ivoire; ${ }^{2}$ Department of Nutri- \\ tion and Food Security, University Nangui Abrogoua, Abidjan, Côte d'Ivoire. \\ Email: ${ }^{2}$ dtheodore33@yahoo.fr
}

Received July $26^{\text {th }}, 2013$; revised August $26^{\text {th }}, 2013$; accepted September $4^{\text {th }}, 2013$

Copyright (C) 2013 Marina C. N. Assohoun et al. This is an open access article distributed under the Creative Commons Attribution License, which permits unrestricted use, distribution, and reproduction in any medium, provided the original work is properly cited.

\begin{abstract}
Investigations were carried out to determine the influence of spontaneous fermentations as achieved at household level on the nutrients composition and aflatoxins concentration of maize during the processing into doklu, a fermented maize food product consumed in Côte d'Ivoire with legumes, soup and fried fish. Results showed that maize grains contained aflatoxin B1, G1 and G2 and that during fermentation all physicochemical parameters significantly $(\mathrm{P} \leq 0.05)$ decreased except moisture and total titratable acidity contents which were significantly $(\mathrm{P} \leq 0.05)$ increased. Fermentation also caused significant reduction in the concentration of total aflatoxins (72\%), with the most important reduction in aflatoxin B1 (80\%) after the soaking of maize grains. However, no aflatoxin was detected after 24 hours of fermentation until the final product was obtained. Despite the losses in some nutritional compounds, the fermented product, doklu, was found to have appreciable nutritional quality.
\end{abstract}

Keywords: Aflatoxins; Doklu; Fermentation; Maize; Proximate Composition

\section{Introduction}

Traditional cereal foods play an important role in the diet of the people of Africa particularly in cereal producing zones. Flour from various cereals is one of the main raw materials used in the production of popular food products with high acceptability, good storage characteristics and affordable cost [1]. These cereals are very widely utilized as food in African countries and account for as much as $77 \%$ of total caloric consumption [2]. Indeed, Cereals have a relatively better mineral profile but the availability of these minerals to human system is low [3]. Phytic acid present in considerable amount in cereal grains [4] may be partly responsible for the low digestibility of starch [5], protein [6] and low bioavailability of minerals $[7,8]$. A majority of traditional cereal based foods consumed in Africa are processed by natural fermentation and are particularly important as weaning foods for infants and as dietary staples for adults $[9,10]$. Fermentation of food grains is known to be an effective method of improving the starch and protein digestibility [11] and *Corresponding author. bioavailability of minerals [4]. Fermentation also brings down the level of antinutrients like phytic acid and polyphenols [7,12].

In Côte d'Ivoire, the indigenous fermented foods are numerous and varied. Doklu is one of these traditional fermented foods produced mainly in the southern parts of country at household level and for family consumption only. It is a snack made from maize flour and eaten at any time of the day. The people often appreciate doklu for its sour taste due to fermentation. In the preparation of doklu, cleaned and washed whole maize grains are steeped in water for 1 or 2 days, milled, mixed into a dough and left to undergo a spontaneous fermentation for 2 - 3 days by desirable microbes in the environment. One portion of the fermented dough is firstly precooked andthen shaped into balls, wrapped in maize husks and boiled for about $3 \mathrm{~h}$ (Figure 1).

Besides improving the digestibility, bioavailability of minerals and reducing the level of antinutrients, fermentation may also change the level of nutrients in the food grains. Indeed, during manufacture of these fermented 


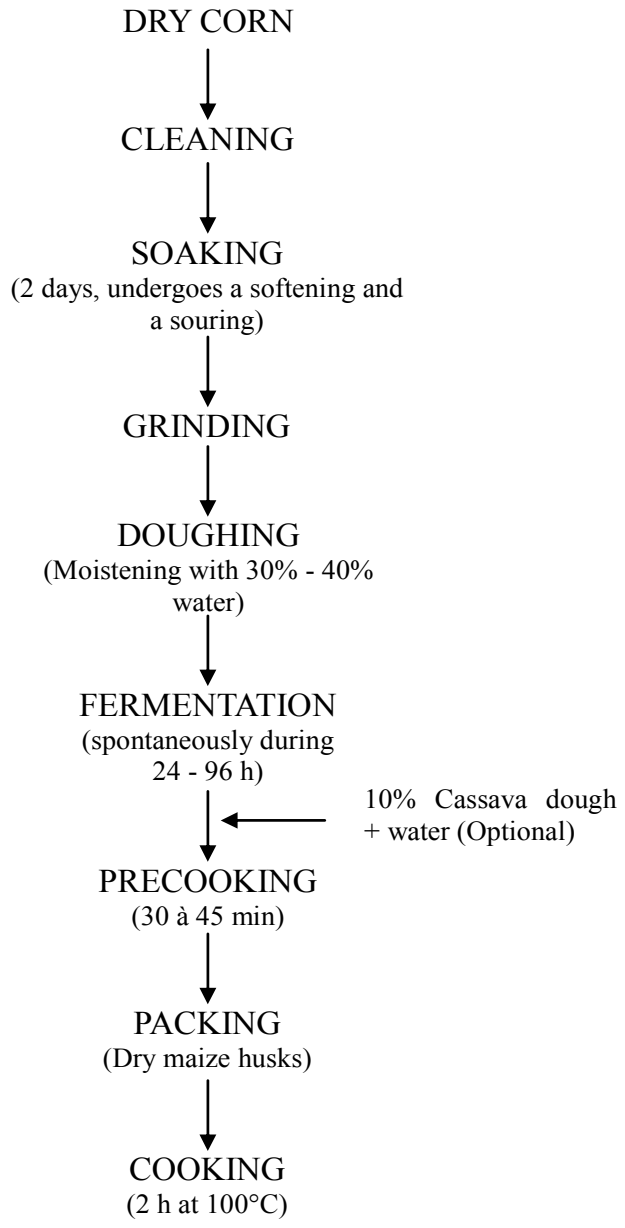

Figure 1. Flow diagram for production of doklu.

cereal foods, nutrients including protein and minerals are lost from the grains thereby affecting nutritional quality adversely, as reported by [13].

This paper reports the effect of spontaneous fermentation as applied at household level on the nutrients composition and aflatoxins rate of maize during the processing into doklu.

\section{Materials and Methods}

\subsection{Sample Collection}

The different samples $(250 \mathrm{~g})$ for this study were collected in sterile containers from 6 processors at different stages of processing (maize grains, milled flours, fermented dough and finished product doklu) in Abidjan (the economic capital of Côte d'Ivoire). All collected samples were immediately transported in an icebox directly to the laboratory for analyses.

\subsection{Proximate Composition}

Forty grams of samples were ground in $300 \mathrm{ml}$ of dis- tilled water in a porcelain mortar and then centrifuged at 4000 tours $/ \mathrm{min}$ for $30 \mathrm{~min}$. The $\mathrm{pH}$ was determined on $50 \mathrm{ml}$ of the supernatant using a pH-meter (P107 Consort). Total titratable acidity was determined by titrating $30 \mathrm{ml}$ of supernatant used for $\mathrm{pH}$ determination against $0.1 \mathrm{M} \mathrm{NaOH}$ using phenolphthalein as indicator. The total titratable acidity was calculated as percentage of lactic acid.

Organic acids of samples were before extracted and then analyzed by high performance liquid chromatography using an ion exclusion ORH-801 column $(300 \mathrm{~mm} \times$ $6.5 \mathrm{~mm}$ ) (Interchrom, France) as achieved by [14]. Running conditions were: mobile phase, $\mathrm{H}_{2} \mathrm{SO}_{4} 40 \mathrm{mmol} \cdot \mathrm{L}^{-1}$; flow rate, $0.8 \mathrm{ml} \cdot \mathrm{min}^{-1}$; wave length, $210 \mathrm{~nm}$; room temperature $\left(25^{\circ} \mathrm{C}\right)$. The separated components were detected with an UV spectrophotometric detector (SPD-6A, Shimadzu Corporation, Japan).

Total sugars content were determined by the phenol sulphuric acid method according to Dubois et al. [15] and the values were expressed in $\mathrm{g} / 100 \mathrm{~g}$ of fresh dough. Total carbohydrates were determined according to the method of [16]. The contents of protein, fat, ash and moisture were determined according to the methods described in [17]. The determination of the energy value was done by calculation according to the method proposed by [18], with specific coefficients of starchy foods:

Energy value $(\mathrm{kcal})=(3.87 \times$ Proteins $)+(4.12 \times$ Total carbohydrates $)+(8.37 \times$ Fats $)$.

\subsection{Mineral Analyses}

The method described by the Association of Official Analytical Chemists [19] was used for mineral analysis. The samples were ashed at $550^{\circ} \mathrm{C}$. The ash was boiled with $10 \mathrm{ml}$ of $20 \%$ hydrochloric acid in a beaker and then filtered into a $100 \mathrm{ml}$ standard flask. This was made up to the mark with deionized water. The minerals were determined from the resulting solution. Sodium $[\mathrm{Na}]$ and Potassium $[\mathrm{K}]$ were determined using the standard flame emission photometer. $\mathrm{NaCl}$ and $\mathrm{KCl}$ were used as the standards [19]. Phosphorus [P] was determined calorimetrically using the spectronic 20 [Gallenkamp, UK] with $\mathrm{KH}_{2} \mathrm{PO}_{4}$ as the standard. Calcium [Ca] was determined using Atomic Absorption Spectrophotometer [AAS Model SP9]. All values were expressed in mg/ $100 \mathrm{~g}$.

\subsection{Aflatoxin Extraction from Maize Samples and HPLC Analysis}

Aflatoxins were extracted after the method of [20], with slight modifications. Twenty (20) g of maize samples collected throughout the doklu process were extracted with $100 \mathrm{ml}$ acetonitrile: potassium chloride $(90: 10, \mathrm{v} / \mathrm{v})$. 
The extract was filtered and the resultant filtrate further purified with a Sepak cleanup column (Merck). Three aliquots $(200 \mu \mathrm{l})$ of the purified extract were transferred into vials. The solvent was evaporated under nitrogen gas and the samples were stored at $4^{\circ} \mathrm{C}$. The dried samples were dissolved in $1 \mathrm{ml}$ acetonitrile: potassium chloride $(1: 1, \mathrm{v} / \mathrm{v})$ and filtered. An aliquot of the filtrate $(300 \mu \mathrm{l})$ was injected into a Shimadzu HPLC system (Shimadzu, model CRB-GA, Kyoto, Japan). Separation was carried out isocratically using $\mathrm{H}_{3} \mathrm{PO}_{4}(0.33 \mathrm{M})$ : acetonitrile: propanol-2 $(650: 400: 50, \mathrm{v} / \mathrm{v} / \mathrm{v})$ as the mobile phase. The flow rate was maintained at $0.5 \mathrm{ml} / \mathrm{min}$ ) and the fluorometric was used. Identification of aflatoxins (B1, B2, G1, and G2) in each sample was achieved by comparison with retention times of standard peaks. A series of each aflatoxin standards were used to construct a calibration curve. The equation obtained from the calibration curve was used to calculate the concentration of aflatoxins in each sample.

\subsection{Statistical Analysis}

The effect of processing steps on the concentration nutrient and aflatoxins in maize samples was analyzed using the analysis of variance (ANOVA) with the use of post hoc tests. Tests with P-values less than 0.05 were considered to be statistically significant.

\section{Results and Discussion}

\subsection{Acid Production in Doklu Fermentation}

The types and amounts of the main acids produced during the process of doklu production are shown in Table 1. Two acids were produced in detectable amounts, namely, lactic and acetic acids. Lactic acid rate was already higher in the maize flour, due to the 2 days soaking stage underwent by maize grains. In fact, according to reference [21], lactic acid bacteria dominate during the soak- ing stage of the traditional process. And as a result, a significant increase of organic acids takes place. The concentrations of these organic acids increased continuously during the fermentation and reached a maximum total of about $1.8 \mathrm{~g} / 100 \mathrm{~g}$ lactic and $0.5 \mathrm{~g} / 100 \mathrm{~g}$ acetic acids the second day of fermentation. After this period, a decrease was observed.The amounts of acids produced in this fermentation are comparable to amounts reported for many other traditional fermented foods. Reference [22] reported $0.78 \%$ lactic acid in ogi, $0.6 \%$ in kaffir beer and $1 \%$ in bussa, three spontaneous fermented cereal based products.

The $\mathrm{pH}$ dropped significantly during the fermentation from 5.4 in the grains to 2.2 at $48 \mathrm{~h}$ contrarily to the total titratable acidity which amount increased to $0.6 \%$ at the same time (Table 1). These are relatively quick variations if compared to similar fermentations, and indicates a relatively high fermentation rate. According to references [23-25], the organic acids released (e.g. lactic, acetic, propionic and butyric acids), as by-products during lactic acid fermentation, lower the $\mathrm{pH}$ to levels of 3 to 4 with a titratable acidity of about $0.6 \%$. The undissociated forms of the acetic and lactic acids at low $\mathrm{pH}$ exhibit inhibitory activities against a wide range of pathogens. This improves food safety by restricting the growth and survival, in fermented cereal beverages, of spoilage organisms and some pathogenic organisms such as Shigella, Salmonella and E. coli $[26,27]$. Fermented maize dough for doklu production with $\mathrm{pH}$ value below 3 could have undoubtedly inhibited the growth of such organisms if they were present.

\subsection{Macronutrient and Mineral Composition}

The macronutrient and mineral composition of samples collected during doklu fermentation are presented in Tables 2 and 3 respectively. The moisture content values of the samples ranged between $14.2 \pm 0.1$ in the grains and

Table 1. Effect of fermentation stages on $\mathbf{p H}$, total titratable acidity and organic acids of maize during its processing into doklu.

\begin{tabular}{cccccc}
\hline & & & Parameters \\
\hline Sampling steps & Products & pH & TTA (\%) & Lactic acid (g/100g) & Acetic acid (g/100g) \\
\hline Maize & Grains & $5.4 \pm 0.1^{\mathrm{a}}$ & $0.02 \pm 0.001^{\mathrm{a}}$ & $\mathrm{nd}$ & $\mathrm{nd}$ \\
Grinding & Flour & $3.2 \pm 0.3^{\mathrm{b}}$ & $0.3 \pm 0.03^{\mathrm{b}}$ & $0.12 \pm 0.03^{\mathrm{a}}$ & $0.04 \pm 0.002^{\mathrm{a}}$ \\
Fermentation & Dough $_{24 \mathrm{~h}}$ & $2.4 \pm 0.2^{\mathrm{cd}}$ & $0.6 \pm 0.01^{\mathrm{c}}$ & $0.7 \pm 0.002^{\mathrm{b}}$ & $0.07 \pm 0.01^{\mathrm{b}}$ \\
& Dough $_{48 \mathrm{~h}}$ & $2.2 \pm 0.1^{\mathrm{d}}$ & $0.6 \pm 0.01^{\mathrm{c}}$ & $1.8 \pm 0.1^{\mathrm{c}}$ & $0.5 \pm 0.01^{\mathrm{c}}$ \\
& Dough $_{72 \mathrm{~h}}$ & $2.7 \pm 0.04^{\mathrm{c}}$ & $0.4 \pm 0.002^{\mathrm{b}}$ & $1.6 \pm 0.2^{\mathrm{d}}$ & $0.2 \pm 0.01^{\mathrm{d}}$ \\
Cooking & Doklu & nd & nd & $1.3 \pm 0.2^{\mathrm{e}}$ & $0.1 \pm 0.04^{\mathrm{d}}$ \\
\hline
\end{tabular}

nd: not detected, data were analyzed on triplicates, Mean values with the same superscript in a column are not significantly different (P $>0.05$ ). TTA: total titratable acidity. 
Table 2. Effect of fermentation stages on proximate composition of maize during its processing into doklu.

\begin{tabular}{ccccccccc}
\hline & \multicolumn{7}{c}{ Parameters } \\
\hline Sampling steps & Products & $\begin{array}{c}\text { Moisture } \\
(\%)\end{array}$ & $\begin{array}{c}\text { Proteins } \\
(\%)\end{array}$ & $\begin{array}{c}\text { Fatty matters } \\
(\%)\end{array}$ & $\begin{array}{c}\text { Carbo hydrates } \\
(\%)\end{array}$ & $\begin{array}{c}\text { Total sugars } \\
(\%)\end{array}$ & $\begin{array}{c}\text { Ash } \\
(\%)\end{array}$ & $\begin{array}{c}\text { Energy value } \\
(\mathbf{K})\end{array}$ \\
\hline Maize & Grains & $14.2 \pm 0.1^{\mathrm{a}}$ & $8.2 \pm 0.7^{\mathrm{a}}$ & $0.64 \pm 0.01^{\mathrm{a}}$ & $60.5 \pm 3.0^{\mathrm{a}}$ & $0.64 \pm 0.01^{\mathrm{a}}$ & $1.85 \pm 0.07^{\mathrm{a}}$ & $280.56^{\mathrm{a}}$ \\
Grinding & Flour & $16.2 \pm 0.3^{\mathrm{b}}$ & $8.1 \pm 0.2^{\mathrm{a}}$ & $0.61 \pm 0.07^{\mathrm{a}}$ & $60.1 \pm 3.3^{\mathrm{a}}$ & $0.62 \pm 0.03^{\mathrm{a}}$ & $1.95 \pm 0.07^{\mathrm{b}}$ & $278.29^{\mathrm{a}}$ \\
Fermentation & Dough $_{24 \mathrm{~h}}$ & $20.5 \pm 0.1^{\mathrm{c}}$ & $7.3 \pm 0.2^{\mathrm{bc}}$ & $0.18 \pm 0.07^{\mathrm{c}}$ & $60.2 \pm 3.01^{\mathrm{a}}$ & $0.24 \pm 0.01^{\mathrm{b}}$ & $1.95 \pm 0.07^{\mathrm{b}}$ & $271.62^{\mathrm{b}}$ \\
& Dough $_{48 \mathrm{~h}}$ & $20.7 \pm 0.2^{\mathrm{c}}$ & $7.1 \pm 0.1^{\mathrm{c}}$ & $0.18 \pm 0.07^{\mathrm{c}}$ & $60.2 \pm 2.2^{\mathrm{a}}$ & $0.19 \pm 0.01^{\mathrm{b}}$ & $1.80 \pm 0.07^{\mathrm{a}}$ & $270.82^{\mathrm{b}}$ \\
& Dough $_{72 \mathrm{~h}}$ & $20.4 \pm 0.2^{\mathrm{c}}$ & $7.1 \pm 0.3^{\mathrm{c}}$ & $0.18 \pm 0.07^{\mathrm{c}}$ & $60.1 \pm 2.1^{\mathrm{a}}$ & $0.16 \pm 0.02^{\mathrm{c}}$ & $1.84 \pm 0.14^{\mathrm{a}}$ & $270.42^{\mathrm{b}}$ \\
& Doklu $_{\text {Cooking }}$ & $20.7 \pm 0.1^{\mathrm{c}}$ & $6.9 \pm 0.1^{\mathrm{cd}}$ & $0.20 \pm 0.07^{\mathrm{c}}$ & $60.2 \pm 3.4^{\mathrm{a}}$ & $0.10 \pm 0.01^{\mathrm{d}}$ & $1.66 \pm 0.2^{\mathrm{c}}$ & $270.2^{\mathrm{b}}$ \\
\hline
\end{tabular}

Data were analyzed on triplicates, mean values with the same superscript in a column are not significantly different $(\mathrm{P}>0.05)$.

Table 3. Effect of fermentation stages on minerals composition of maize during its processing into doklu.

\begin{tabular}{cccccc}
\hline & & \multicolumn{3}{c}{ Minerals (\%) } \\
\hline Sampling steps & Products & Ca & P & K & Na \\
\hline Maize & Grains & $0.05 \pm 0.003^{\mathrm{a}}$ & $0.17 \pm 0.07^{\mathrm{a}}$ & $0.02 \pm 0.003^{\mathrm{a}}$ & $0.01 \pm 0.007^{\mathrm{a}}$ \\
Grinding & Flour & $0.05 \pm 0.003^{\mathrm{a}}$ & $0.17 \pm 0.01^{\mathrm{a}}$ & $0.02 \pm 0.003^{\mathrm{a}}$ & $0.01 \pm 0.007^{\mathrm{a}}$ \\
Fermentation & Dough $_{24 \mathrm{~h}}$ & $0.03 \pm 0.01^{\mathrm{a}}$ & $0.14 \pm 0.07^{\mathrm{a}}$ & $0.02 \pm 0.003^{\mathrm{a}}$ & $0.01 \pm 0.007^{\mathrm{a}}$ \\
& Dough $_{48 \mathrm{~h}}$ & $0.03 \pm 0.01^{\mathrm{a}}$ & $0.14 \pm 0.05^{\mathrm{a}}$ & $0.02 \pm 0.003^{\mathrm{a}}$ & $0.01 \pm 0.007^{\mathrm{a}}$ \\
& Dough $_{72 \mathrm{~h}}$ & $0.03 \pm 0.003^{\mathrm{a}}$ & $0.14 \pm 0.07^{\mathrm{a}}$ & $0.02 \pm 0.003^{\mathrm{a}}$ & $0.01 \pm 0.007^{\mathrm{a}}$ \\
& Doklu & $0.03 \pm 0.003^{\mathrm{a}}$ & $0.14 \pm 0.01^{\mathrm{a}}$ & $0.02 \pm 0.003^{\mathrm{a}}$ & $0.01 \pm 0.007^{\mathrm{a}}$ \\
\hline
\end{tabular}

Data were analyzed on triplicates, mean values with the same superscript in a column are not significantly different $(\mathrm{P}>0.05)$.

$20.7 \% \pm 0.1 \%$ for the final product. This variation in the moisture content is due to the fact that an amount of water is added to the maize flour to make the dough. However, the value obtained for the final product is different of those stated by [28] for kenkey, a similar maize food from Ghana. Moreover, scientific investigation has reported that low moisture content in food samples increased the storage periods of the food products [29]; while high moisture content in foods encourage microbial growth; hence, food spoilage [30].

The proteins, fatty matters and total soluble sugars contents were respectively of $8.2 \pm 0.7,0.64 \pm 0.01$ and $0.64 \% \pm 0.01 \%$ in maize grains (Table 2 ). These values were significantly reduced during the process of doklu production. As a result of fermentation significant reducetion in crude protein and soluble sugars contents of the food may be attributed in one hand to an increase in protein catabolism by the fermenting microorganisms which leads to the escape of the by-product of metabolic deamination, i.e. ammonia and in other hand to the utilization of sugars as a carbon source. The results are similar to those reported by [31] who observed a reduction in protein content of fermented cereal-legume food mixtures by the action of bacteria and yeasts. Reference [32] also noticed a significant reduction in the protein content of pearl millet when it was fermented with L. acidophilus. According to Reference [33], fermentation may slightly alter the proximate composition substrates. A slight increase in the percentage of protein can be noted. This increase reflects the decrease of other constituents which the microorganisms might have consumed for growth. The decrease of soluble sugars and fatty matters in maize dough during doklu fermentation suggested that the fermenting microorganisms had used them as an energy source. Reduction of fat content was previously mentioned by [34] in their study on the fermentation of pear millet.

Ash content of maize seeds was $1.85 \%$ and this value was significantly affected during the various stage of processing (Table 2), whilst mineral contents and energy value remained unaffected by the fermentation process (Table 3). A similar trend was observed during the fermentation of cassava during fufu production by [35] These authors showed that the fermentation process caused an increase in the concentration of calcium $(+12 \%)$ in cassava but reductions in the levels of potassium, sodium, manganese, iron, copper, zinc and phosphorus. Data have not been published on changes in the 
caloric content of food as a result of fermentation processes. Generally only small changes would be expected. In processes such as tempeh production, which are aerobic, the fermentation period is too short to allow large decreases in the total lipids, carbohydrate, or protein components of the food [36].

\subsection{Effect on Aflatoxins Rate}

Figure 2 shows the high-performance liquid chromatogram of aflatoxins B1, G1 and G2 extracted from maize grains samples. As it could be seen on the figure, aflatoxin B2 was not detected in maize grains and consequently during all the process of doklu production.

The total amount of aflatoxins detected in the grains was $4.59 \pm 0.03 \mu \mathrm{g} / \mathrm{kg}$ consisting in $2.52 \pm 0.01 \mu \mathrm{g} / \mathrm{kg}$ of aflatoxin B1, $2.52 \pm 0.01 \mu \mathrm{g} / \mathrm{kg}$ of aflatoxin G1 and 0.33 $\pm 0.02 \mu \mathrm{g} / \mathrm{kg}$ aflatoxin G2 (Table 4). Maize and maize products are known to be susceptible to contamination by fungi that produce secondary metabolites such as aflatoxins [37]. Aflatoxins have been described as extremely toxic and carcinogenic compounds, which appear to be ubiquitous in the environment [38]. The incidence and level of aflatoxin contamination in various food commodities have been monitored worldwide [19] and continues to be of great concern. Aflatoxins, particularly aflatoxin B1 (AFB1), are considered to be the most important of the mycotoxins due to their high toxicity and they are still of major concern to the feed industry and farmers as many raw materials which are used as components of animal feeds are prone to contamination [39]. Their adverse effects involves their mutagenic, carcinogenic (especially to kidneys and liver), teratogenic and oestrogen immunosuppressive effects. Aflatoxin B1 is one of the strongest carcinogens and it was included by WHO and the International Agency for Research on Cancer in the list of carcinogenic substances Group I, i.e. substances with confirmed carcinogenic effect in humans $[40,41]$. However, during processing of maize into doklu, important decreases in aflatoxins rates were observed (Table 4). After the 2 days soaking, the amount of afla- toxins was reduced to $1.3 \pm 0.04 \mu \mathrm{g} / \mathrm{kg}$ (about $72 \%$ ) for total aflatoxins and to $0.51 \pm 0.02 \mu \mathrm{g} / \mathrm{kg}$ (about $80 \%$ ) for aflatoxin B1. At the fermentation steps no aflatoxin was detected, involving that all the mycotoxins degraded. This study has shown that natural fermentation of maize dough for doklu production can substantially reduce the amount of aflatoxins contamining the raw material. The toxicity of the product was significantly reduced after the soaking and the first time fermentation period with progressive decrease in the $\mathrm{pH}$. This is in agreement with other studies, which clearly show that lactic acid bacteria (Lactobacillus strains) efficiently remove aflatoxin B1 from the culture solution $[42,43]$. It has been suggested that removal of toxins is through noncovalent binding of mutagens by fractions of the cell wall skeleton of lactic acid bacteria [44]. However, other alternative mechanism of aflatoxin B1 removal has been reported, in which LAB fermentation opens up the aflatoxin B1 lactone ring resulting in its complete detoxification [45]. The lower $\mathrm{pH}$ of the media could also have contributed to the removal of toxins from the media as other studies have shown that treatment of LAB pellets with hydrochloric acid significantly enhanced the binding ability of the bacteria [36].

\subsection{Conclusion}

It may be concluded from this study that natural fermentation during the processing of maize grains into doklu resulted in reduction of some nutritional parameters, but a high increase in acidity, an important characteristic for the product safety was observed. Natural fermentation also leads to a total elimination of aflatoxins in the product. Despite the losses in some nutritional compounds, the fermented product, doklu, was found to have appreciable nutritional quality.

\section{Acknowledgements}

This research was made possible through funds provided by the International Foundation for Science, Sweden

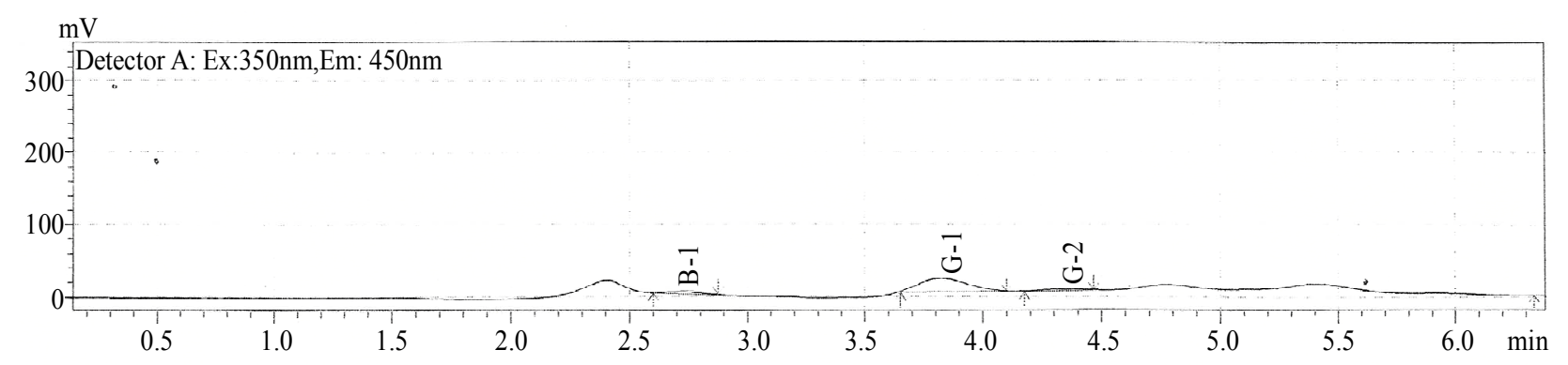

Figure 2. Typical high-performance liquid chromatogram of extract of maize grains samples showing picks of aflatoxins B1, G1, G2 and their retention times. 
Table 4. Effect of fermentation stages on aflatoxins content of maize during its processing into doklu.

\begin{tabular}{|c|c|c|c|c|c|c|}
\hline \multirow[b]{2}{*}{ Sampling steps } & \multirow[b]{2}{*}{ Products } & \multicolumn{5}{|c|}{ Aflatoxins $(\boldsymbol{\mu g} / \mathbf{k g})$} \\
\hline & & AFB1 & AFB2 & AFG1 & AFG2 & Total \\
\hline Maize & Grains & $2.52 \pm 0.01^{\mathrm{a}}$ & nd & $2.52 \pm 0.01^{\mathrm{a}}$ & $0.33 \pm 0.02$ & $4.59 \pm 0.03^{\mathrm{a}}$ \\
\hline Grinding & Flour & $0.51 \pm 0.02^{\mathrm{b}}$ & nd & $0.80 \pm 0.02^{\mathrm{b}}$ & nd & $1.3 \pm 0.04^{\mathrm{b}}$ \\
\hline \multirow[t]{3}{*}{ Fermentation } & Dough $_{24 h}$ & nd & nd & nd & nd & nd \\
\hline & Dough $_{48 \mathrm{~h}}$ & nd & nd & nd & nd & nd \\
\hline & Dough $_{72 \mathrm{~h}}$ & nd & nd & nd & nd & nd \\
\hline Cooking & Doklu & nd & nd & nd & nd & nd \\
\hline
\end{tabular}

nd: not detected, data were analyzed on triplicates, mean values with the same superscript in a column are not significantly different $(\mathrm{P}>0.05)$.

(E/4955-1). The authors gratefully acknowledge $M$. SORO and M. OUATTARA from LANADA for their assistance in HLPC analysis for aflatoxins quantification.

\section{REFERENCES}

[1] T. I. Mbata, M. J. Ikenebomeh and J. C. Alaneme, "Studies on the Microbiological, Nutrient Composition and Antinutritional Contents of Fermented Maize Flour Fortified with Bambara Groundnut (Vigna subterranean L)," African Journal of Food Science, Vol. 3, No. 6, 2009, pp. 165-171.

[2] O. O. Taiwo, "Physical and Nutritive Properties of Fermented Cereal Foods," African Journal of Food Science, Vol. 3, No. 2, 2009, pp. 23-27.

[3] S. Mahajan and B. M. Chauhan, "Phytic Acid and Extractable Phosphorus of Pearl Millet Flour as Affected by Natural Lactic Acid Fermentation," Journal of the Science of Food and Agriculture, Vol. 41, No. 4, 1987, pp. 381-382. http://dx.doi.org/10.1002/jsfa.2740410410

[4] B. M. Chauhan, N. Suneja and C. M. Bhat, "Nutritional Value and Fatty Acid Composition of Some High Yielding Varieties of bajra," Bulletin of Grain Technology, Vol. 21, 1986, pp. 441-442.

[5] N. Dhankher and B. M. Chauhan, "Effect of Temperature and Period of Fermentation on the Protein and Starch Digestibility (in Vitro) of rabadi-A Pearl Millet Fermented Food," Journal of Food Science, Vol. 52, No. 2, 1987, pp. 489-490. http://dx.doi.org/10.1111/j.1365-2621.1987.tb06648.x

[6] N. Dhankher and B. M. Chauhan, "Effect of Temperature and Fermentation Time on Phytic Acid and Polyphenol Content of rabadi-A Fermented Pearl Millet Food," Journal of Food Science, Vol. 52, No. 3, 1987, pp. 828829. http://dx.doi.org/10.1111/j.1365-2621.1987.tb06739.x

[7] K. B. Nolan and P. A. Duffin, "Effect of Phytate on Mineral Bioavailability. In Vitro Studies on $\mathrm{Mg}^{2+}, \mathrm{Ca}^{2+}, \mathrm{Fe}^{3+}$ and $\mathrm{Zn}^{2+}$ in the Presence of Phytate," Journal of the Science of Food and Agriculture, Vol. 40, No. 1, 1987, pp. 79-83. http://dx.doi.org/10.1002/jsfa. 2740400110
[8] Q. Liu, E. Donner, Y. Yin, R. L. Huang and M. Z. Fan, "The Physicochemical Properties and in Vitro Digestibility of Selected Cereals, Tubers and Legumes Grown in China," Food Chemistry, Vol. 99, No. 3, 2006, pp. 470477. http://dx.doi.org/10.1016/j.foodchem.2005.08.008

[9] E. N. T. Akobundu and F. H. Hoskins, "Protein Losses in Traditional agidi Paste," Journal of Food Science, Vol. 47, No. 5, 1982, pp. 1728-1729. http://dx.doi.org/10.1111/j.1365-2621.1982.tb05021.x

[10] V. Umoh and M. J. Fields, "Fermentation of Corn for Nigerian Agidi," Journal of Food Science, Vol. 46, No. 3, 1981, pp. 903-905. http://dx.doi.org/10.1111/j.1365-2621.1981.tb15376.x

[11] M. A. M. Ali, A. H. El-Tinay and Abdalla, "Effect of Fermentation on in Vitro Protein Digestibility of Pearl Millet," Food Chemistry, Vol. 80, No. 1, 2003, pp. 51-54. http://dx.doi.org/10.1016/S0308-8146(02)00234-0

[12] A. Sharma and N. Khetarpaul, "Effect of Fermentation on Phytic Acid Content and in Vitro Digestibility of Starch and Protein of Rice-Black Gram Dhal-Whey Blends," Journal of Food Science and Technology, Vol. 34, 1997, pp. 20-22.

[13] E. R. Aminigo and J. O. Akingbala, "Nutritive Composition and Sensory Properties of Ogi Fortified with Okra Seed Meal," Journal of Applied Science and Environment Management, Vol. 8, No. 2, 2004, pp. 23-28.

[14] N. T. Djeni, K. F. N'guessan, D. M. Toka, K. A. Kouame and K. M. Dje, "Quality of attieke (a Fermented Cassava Product) from the Three Main Processing Zones in Côte d'Ivoire," Food Research International, Vol. 44, No. 1, 2011, pp. 410-416. http://dx.doi.org/10.1016/j.foodres.2010.09.032

[15] M. Dubois, K. A. Gilles, J. K. Hamilton, P. A. Rebers and F. Smith, "Colorimetric Method for Determinations of Sugars and Related Substances," Analytical Chemistry, Vol. 28, No. 3, 1956, pp. 350-356. http://dx.doi.org/10.1021/ac60111a017

[16] FAO, "Food Energy-Methods of Analysis and Conversion Factors," Report of a Technical Workshop, Rome, 3-6 December 2002, FAO Food and Nutrition Paper 77, $93 \mathrm{p}$. 
[17] AOAC, "Official Methods of Analysis," 16th Edition, Vol. 1-2, Association of Official Analytical Chemists, Arlington, 1998

[18] FAO, "Composition des Aliments en Principes Nutritifs Calorigènes et Calcul des Valeurs Energétiques Utiles," Rapport du Comité Chargé de l'Etude des Aliments et des Facteurs de la Division de la Nutrition de la FAO, Washington DC, 1947, $30 \mathrm{p}$.

[19] AOAC, "Official Methods of Analysis of AOAC International," 18th Edition, Association of Analytical Communities Gaithersburg, 2005.

[20] A. E. Ce'spedes and G. J. Diaz, "Analysis of Aflatoxins in Poultry and Pig Feeds and Feedstuffs Used in Columbia," Journal AOAC International, Vol. 80, No. 6, 1997 , pp. 1215-1219.

[21] R. K. Mulyowidarso, G. H. Fleet and K. A. Buckle, "Changes in the Concentration of Organic Acids during the Soaking of Soybeans for tempe Production," International Journal of Food Science and Technology, Vol. 26, No. 6, 1991, pp. 607-614. http://dx.doi.org/10.1111/j.1365-2621.1991.tb02006.x

[22] S. A. Odunfa and S. Adeyde, "Microbiological Changes during the Traditional Production of ogibaba, a West African Fermented Sorghum Gruel," Journal of Cereal Science, Vol. 3, No. 2, 1985, pp. 173-180. http://dx.doi.org/10.1016/S0733-5210(85)80027-8

[23] W. H. Holzapfel, “Appropriate Starter Culture Technologies for Small-Scale Fermentation in Developing Countries," International Journal of Food Microbiology, Vol. 75, No. 3, 2002, pp. 197-212. http://dx.doi.org/10.1016/S0168-1605(01)00707-3

[24] M. O. Edema and A. I. Sanni, "Functional Properties of Selected Starter Cultures for Sour Maize Bread," Food Microbiology, Vol. 25, No. 4, 2008, pp. 616-625. http://dx.doi.org/10.1016/j.fm.2007.12.006

[25] P. Mensah, "Fermentation-The Key to Food Safety Assurance in Africa?" Food Control, Vol. 8, No. 5-6, 1997, pp. 271-278.

http://dx.doi.org/10.1016/S0956-7135(97)00020-0

[26] A. Blandino, M. E. Al-Aseeri, S. S. Pandiella, D. Cantero and C. Webb, "Cereal-Based Fermented Foods and Beverages," Food Research International, Vol. 36, No. 6, 2003, pp. 527-543. http://dx.doi.org/10.1016/S0963-9969(03)00009-7

[27] N. B. Omar, H. Abriouel, R. Lucas, M. Martinez-Caňamero, J. Guyot and A. Gálvez, "Isolation of Bacteriocinogenic Lactobacillus plantarum Strains from ben saalga, a Traditional Fermented Gruel from Burkina Faso," International Journal of Food Microbiology, Vol. 112, No. 1, 2006, pp. 44-50. http://dx.doi.org/10.1016/i.ijfoodmicro.2006.06.014

[28] A. Annan-Prah and J. A. Agyeman, "Nutrient Content and Survival of Selected Pathogenic Bacteria in kenkey Used as a Weaning Food in Ghana," Acta Tropica, Vol. 65 , No. 1, 1997, pp. 33-42. http://dx.doi.org/10.1016/S0001-706X(97)00650-5

[29] Y. E. Alozie, M. A. Iyam, O. Lawal, U. Udofia and I. F. Ani, "Utilization of Bambara Ground Flour Blends in
Bread Production," Journal of Food Technology, Vol. 7 , No. 4, 2009, pp. 111-114.

[30] V. J. Temple, E. J. Badamosi, O. Ladeji and M. Solomon, "Proximate Chemical Composition of Three Locally Formulated Complementary Foods in West African," Journal of Biological Sciences, Vol. 5, 1996, pp. 134-143.

[31] Binita, N. Khetarpaul and R. Kumar, "Development, Acceptability and Nutritional Composition of Food Blends Fermented with Probiotic Organisms," Annals of Biology, Vol. 12, 1996, pp. 127-133.

[32] A. Sharma, "Fermentative Improvement of Pearl Millet and Utilization of the Fermented Product," Ph.D. Thesis Dissertation, Haryana Agricultural University, Hisar, 1994.

[33] H. L. Wang, "Nutritional Quality of Fermented Foods," In: C. W. Hesseltine and H. L. Wang, Eds., Mycologia Memoir No. 11, Indigenous Fermented Food of Non-Western Origin, 1968, pp. 289-301.

[34] N. Khetarpaul and B. M. Chauhan, "Effect of Fermentation on Protein, Fat, Minerals and Thiamine Content of Pearl Millet," Plant Foods for Human Nutrition, Vol. 39, No. 2, 1989, pp. 169-177. http://dx.doi.org/10.1007/BF01091897

[35] O. B. Oyewole and S. A. Odunfa, "Effects of Fermentation on the Carbohydrate, Mineral, and Protein Contents of Cassava during 'Fufu' Production," Journal of Food Composition and Analysis, Vol. 2, No. 2, 1989, pp. 170176. http://dx.doi.org/10.1016/0889-1575(89)90078-1

[36] R. F. McFeeters, "Effects of Fermentation on the Nutritional Properties of Food," In: E. Karmas and R. S. Harris, Eds., Nutritional Evaluation of Food Processing, Van Nostrand Reinhold Co., New York, 1988, pp. 423-446. http://dx.doi.org/10.1007/978-94-011-7030-7 16

[37] M. P. Mokoena, P. K. Chelule and N. Gqaleni, "The Toxicity and Decreased Concentration of Aflatoxin B1 in Natural Lactic Acid Fermented Maize Meal," Journal of Applied Microbiology, Vol. 100, No. 4, 2006, pp. 773 777. http://dx.doi.org/10.1111/j.1365-2672.2006.02881.x

[38] T. E. Massey, R. K. Steewart, J. M. Daniels and L. Liu, "Biochemical and Molecular Aspects of Mammalian Susceptibility to Aflatoxin B1 Carcinogenicity," Proceedings of the Society for Experimental Biology and Medicine, Vol. 208, No. 3, 1995, pp. 213-227. http://dx.doi.org/10.3181/00379727-208-43852A

[39] K. Śliżewska and S. Smulikowska, "Detoxification of Aflatoxin B1 and Change in Microflora Pattern by Probiotic in Vitro Fermentation of Broiler Feed," Journal of Animal and Feed Sciences, Vol. 20, 2011, pp. 300-309.

[40] JECFA, "Safety Evaluation of Certain Food Additives and Contaminants Aflatoxins," WHO Food Additives Series, Vol. 40, 1998, pp. 897-913.

[41] FAO/WHO/UNEP, "Mycotoxin Prevention and Decontamination, HACCP and Its Mycotoxin Control Potential: An Evaluation of Ochratoxin A in Coffee Production," Third Joint FAO/WHO/UNEP International Conference on Mycotoxins, 1999, pp. 1-13.

[42] H. el-Nezami, P. Kankaanpaa, S. Salminen and J. Ahokas, "Physicochemical Alterations Enhance the Ability of 
Dairy Strains of Lactic Acid Bacteria to Remove Aflatoxin from Contaminated Media," Journal of Food Protection, Vol. 61, No. 4, 1998, pp. 466-468.

[43] C. A. Haskard, H. S. El-Nezami, P. E. Kankaanpaa, S. Salminen and J. T. Ahokas, "Surface Binding of Aflatoxin $\mathrm{B}_{1}$ by Lactic Acid Bacteria," Applied and Environmental Microbiology, Vol. 67, No. 7, 2001, pp. 30863091.

http://dx.doi.org/10.1128/AEM.67.7.3086-3091.2001
[44] X. B. Zhang and Y. Ohta, "Binding of Mutagens by Fractions of the Cell Wall Skeleton of Lactic Acid Bacteria on Mutagens," Journal of Dairy Science, Vol. 74, No. 5, 1991, pp. 1477-1481.

http://dx.doi.org/10.3168/jds.S0022-0302(91)78306-9

[45] N. J. R. Nout, "Fermented Foods and Food Safety," Food Research International, Vol. 27, No. 3, 1994, pp. 291-298. http://dx.doi.org/10.1016/0963-9969(94)90097-3 